\title{
W poszukiwaniu optymalnej formy państwa u progu niepodległości. Królestwo Finlandii i Królestwo Litwy z 1918 r.
}

I. I wojna światowa stanowi ważną cezurę w dziejach europejskich monarchii. Wyznacza kres porządku ukształtowanego na mocy ustaleń kongresu wiedeńskiego z 1815 r., które stanowiły podstawę najbardziej ustabilizowanego i produktywnego wieku w dotychczasowych dziejach ludzkości ${ }^{1}$. „Wielka wojna” rozpoczęła się w Europie, w której istniały zaledwie trzy republiki (nie licząc najstarszej, ale również najmniejszej republiki europejskiej - San Marino): Francja, Portugalia i Szwajcaria. Bilans wojny i kolejnych kilku lat okazał się dla państw monarchicznych zdecydowanie ujemny. W tych państwach, gdzie utrzymały się rządy monarchiczne, jak w Zjednoczonym Królestwie, we Włoszech, w Szwecji, Belgii czy Niderlandach, królowie nie mieli już sprawować realnej władzy, stopniowo ograniczani w swoich funkcjach do ról ceremonialno-protokolarnych ${ }^{2}$. Wielkie monarchie Romanowych, Hohenzollernów i Habsburgów w ogóle przestały istnieć, a na ich ruinach powstały

1 P. Johnson, Historia świata od roku 1917 do lat 90-tych, Londyn 1993, s. 27.

2 S. Grodziski, Porównawcza historia ustrojów państwowych, Kraków 2008, s. 327-329. 
liczne państwa narodowe, które w absolutnej większości przyjęły reżim republikański.

Te wydarzenia stały się podstawą dla określenia I wojny światowej jako starcia dwóch ideologii - monarchicznej, której ucieleśnieniem była Austria, oraz republikańskiej, symbolizowanej przez Stany Zjednoczone ${ }^{3}$. Cesarstwo Austro-Węgierskie wyszło z I wojny jako niewielkie państwo, ledwie cień dawnej potęgi, do tego - republika. Stany Zjednoczone awansowały do rangi mocarstwa światowego i pozycję tę utrzymały przez cały XX wiek. Konsekwencją wojny miał być koniec ancieme regime'u opartego na monarchiach oraz nastanie epoki demokratycznych republik i powszechnego prawa wyborczego, określanych jako pax Americana 4 . Teza o konflikcie ideologicznym, w który przerodziła się I wojna światowa, i jego republikańskim zwycięzcy jest interesująca, jednak jak każde uogólnienie pomija wiele istotnych niuansów.

Nie ulega wątpliwości, że jednym z podstawowych celów polityki prezydenta USA W. Wilsona była budowa nowego ładu w Europie, opartego na sprawiedliwości i równouprawnieniu narodów. W czasie przemówienia do Kongresu z okazji przystąpienia USA do wojny 2 IV 1917 r. Wilson wprost stwierdził, że „trzeba uczynić świat bezpiecznym dla demokracji” ${ }^{5}$. Określanie przez ententę działań wojennych jako walki o demokrację, a zwycięstwa jako „tryumfu wielkich demokracji Zachodu" było pod koniec wojny powszechne. Istotny był tutaj fakt, że przeciwnikiem były państwa postabsolutne, a odpowiedzialnią za wybuch wojny obarczano klasy i elity rządzące. „Demokracja dla wszystkich” miała stać się receptą na nowy, pokojowy swiat ${ }^{6}$.

Wcielanie idei demokratycznych w powojennej Europie centralnej i wschodniej nie oznaczało samo w sobie zwalczania monarchii. Należy pamiętać, że państwa monarchiczne znalazły się w obu wrogich obozach. Stany Zjednoczone prowadzące wojnę z Cesar-

${ }^{3}$ H.H. Hoppe, Demokracja - bóg, który zawiódt. Ekonomia i polityka demokracji, monarchii $i$ ładu naturalnego, Warszawa 2010, s. 3-6.

4 Ibidem, s. 42-43, 50-51.

5 P. Johnson, op.cit., s. 46.

6 J. Baszkiewicz, Władza, Wrocław 2009, s. 141. 
stwem Austro-Węgier czy Cesarstwem Niemiec znalazły się w sojuszu z Cesarstwem Rosji czy Zjednoczonym Królestwem Wielkiej Brytanii i Irlandii Północnej. W działalności polityków amerykańskich tego okresu można co prawda dostrzec przejawy antymonarchicznych poglądów ${ }^{7}$, ale były one związane raczej $z$ układem sojuszy, a nawet prywatnymi poglądami urzędników niż z jakąś nadrzędną antykrólewską ideologią. Odwołując się do konkretnego przykładu - chłodny początkowo stosunek USA do niepodległościowych dążeń Finlandii wynikał raczej z obaw dotyczących osłabienia sojusznika, którym była Rosja (Wielkie Księstwo Finlandii było częścią Cesarstwa Rosyjskiego) - względnie niechęcią wobec osoby proponowanego fińskiego monarchy, którym został Niemiec niż antymonarchizmem. Na przełomie XIX i XX w. również monarchie weszły na drogę demokracji ${ }^{8}$. Proces ten przebiegał łatwiej i szybciej w republikach, ale był możliwy i odbywał się również w monarchiach $^{9}$.

Głównym wyzwaniem, przed którym stanęli budowniczowie powojennego ładu, nie był monarchizm, ale irredentyzm jako pokłosie rozpadu wielonarodowych monarchii ${ }^{10}$. Ich rozpad był nieunikniony, szczególnie wobec coraz liczniejszych konfliktów wewnętrznych na tle etnicznym mających miejsce w ciągu kilku dekad poprzedzających wybuch I wojny światowej ${ }^{11}$. Monarchie w Europie Środkowoschodniej były jedynym czynnikiem spajającym państwa wielonarodowe, unifikującym liczne grupy narodowe i etniczne oraz

7 J. Suchoples, Finlandia w polityce Stanów Zjednoczonych 1917-1919, Warszawa 2002, s. 31.

8 S. Grodziski określa demokrację jako ustrój, w którym a) źródłem władzy jest wola większości i b) wszystkim obywatelom przyznaje się prawa zapewniające im udział w sprawowaniu władzy (op.cit., s. 326).

9 Ibidem, s. 327.

10 Termin ,irredentyzm” wywodzi się od włoskiego risorgimento i oznacza dążenie jakiejś grupy narodowej do utworzenia własnego państwa (P. Johnson, op.cit., s. 30).

11 P. Johnson podaje liczne przykłady konfliktów etnicznych na terytorium Austro-Węgier: Węgrów, Rumunów i Słowaków, Polaków i Ukraińców, Czechów i Słowaków czy Słoweńców i Włochów (ibidem, s. 50-51). 
gwarantującym ich względną równość. Naturalną konsekwencją ich upadku był wzmożony rozwój kiełkujących od dłuższego czasu idei nacjonalistycznych wzmocniony postulatem samostanowienia narodów. Wspieranie procesu powstawania nowych państw jako wyrazu dążeń niepodległościowych samych narodów wydawało się oczywiste. Pojawiły się jednak dwa istotne problemy.

Po pierwsze - również w skład imperiów Francji i Wielkiej Brytanii wchodziły wielorasowe i wielojęzyczne terytoria. Anglicy mieli ponadto lokalny problem irredenty w Irlandii. Nie dziwi ich daleko posunięta rezerwa wobec idei samostanowienia narodów. Skuteczny czynnik osłabiający wielonarodowe monarchie - głównego przeciwnika w wojnie ${ }^{12}$ - mógł się okazać bronią obosieczną. Koniec wojny i upadek wielkich monarchii w Europie Środkowowschodniej nadały problemowi irredentyzmu pierwszorzędne znaczenie.

Po drugie - w przypadku narodów niemających własnego państwa, dla których pierwszorzędną kwestią było jego ustanowienie, kluczowe było udzielenie odpowiedzi na pytanie dotyczące formy przyszłego państwa. Wybór republikańskiej formy rządów doskonale wpisywałby się w hasło nowego porządku opartego na ideach demokratycznych. Okazało się, że dla narodów budujących swoją państwowowść na ruinach wielonarodowych monarchii wybór ten nie był bezalternatywny. Idea monarchii okazała się na tyle atrakcyjna, że odwołało się do niej kilka młodych państw narodowych.

Niniejsze opracowanie ma na celu prezentację dwóch przykładów ustrojowego eksperymentu, polegającego na posłużeniu się ideą monarchii dla realizacji postulatu samostanowienia narodów - fińskiego i litewskiego. Oba okazały się efemeryczne, przez co są w literaturze na ogół pomijane lub traktowane marginalnie. Zadaniem, jakie postawił sobie autor, jest próba udzielenia odpowiedzi na pytanie o powody wyboru monarchicznej formy ustrojowej przez powstające, młode państwa narodowe, a także oceny tego wyboru.

II. Finlandia, dotychczasowa prowincja Szwecji, uzyskała status Wielkiego Księstwa w wyniku zajęcia ziem fińskich przez Rosję (1808 r.) i zrzeczenia się przez króla szwedzkiego wszelkich praw

12 Ibidem, s. 31-32. 
do Finlandii (1809 r.) ${ }^{13}$. Proklamując powstanie Wielkiego Księstwa Finlandii, car potwierdził moc obowiązującą szwedzkiego Aktu o Formie Rządu z 1772 r. oraz Aktu Zjednoczenia i Bezpieczeństwa z 1789 r. wzmacniających pozycję monarchy. Krok ten, podyktowany chęcią utrzymania ciągłości prawnoustrojowej, okazał się mieć istotne znaczenie dla decyzji o powołaniu Królestwa Finlandii po I wojnie światowej i jego kształcie ustrojowym. Wspomniane akty, z późniejszymi zmianami, stanowiły podstawę ustroju Finlandii do 1918 r. (w Szwecji obowiązywały tylko do 1809 r. ${ }^{14}$ ).

Pytanie o status Wielkiego Księstwa Finlandii w momencie jego ustanowienia i włączenia w skład Imperium Rosyjskiego wzbudza dyskusje wśród badaczy. Część uważa, że Finlandia została włączona w skład Rosji jako jedna $z$ dawnych prowincji szwedzkich, inni - że w momencie wyzwolenia się spod panowania szwedzkiego monarchy i uzyskania statusu Wielkiego Księstwa Finlandia stawała się odrębną jednostką polityczną o oryginalnym statusie ustrojowym, odrzucając tym samym tezę o unii realnej z Rosją ${ }^{15}$. Fakt obowiązywania w Finlandii przepisów ustrojowych odrębnych od rosyjskich (co prawda o szwedzkiej proweniencji, ale wkrótce uchylonych w samej Szwecji) pozwala mówić o oryginalnym, fińskim dorobku prawnoustrojowym.

Car, powołując się na postanowienia Aktu z 1772 r., zwołał w 1809 r. czterostanowe zgromadzenie reprezentantów i zadeklarował wolę zachowania tradycyjnego systemu ustrojowego i prawnego. Funkcjonowanie parlamentu zostało następnie zamrożone na ponad 50 lat, zwanych okresem „zamrożonego konstytucjonali-

13 Było to efektem porozumienia Napoleona Bonaparte i cara Aleksandra I. W zamian za wystąpienie przeciwko Szwecji, która nie chciała podporządkować się francuskiej polityce „blokady kontynentalnej”, Napoleon obiecał Rosjanom Finlandię. Wojska rosyjskie szybko złamały opór armii szwedzko-fińskiej. Król szwedzki Gustaw IV Adolf w traktacie pokojowym z 17 IX 1809 r. zrzekł się wszelkich praw do Finlandii i Wysp Alandzkich (S. Sagan, V. Serzhanova, Konstytucja Finlandii - wstęp, Rzeszów 2003, s. 22-23).

14 J. Osiński, Konstytucja Finlandii. Wstęp, Warszawa 2003, s. 10.

15 S. Sagan, V. Serzhanova, op.cit., s. 23-24. 
zmu" ${ }^{16}$. Odwołanie się do Aktu o Formie Rządu z 1772 r. - prawnego fundamentu szwedzkiej oświeconej monarchii absolutnej ${ }^{17}$, jednoznacznie dowodzi intencji cara. Centralna administracja podporządkowana została Radzie Rządowej (w 1816 r. przemianowanej na Senat), której 14 członków i przewodniczącego generał-gubernatora mianował monarcha. Dopiero w 1863 r. car Aleksander II, realizując program reform państwowych, zwołał do Helsinek kolejne zgromadzenie stanowe, które uchwaliło kilkadziesiąt ustaw ustrojowych $^{18}$. Zwierzchnia pozycja monarchy nie uległa osłabieniu, ale już sam fakt zwołania parlamentu miał znaczenie symboliczne, które wpłynęło na proces budzenia się fińskiej świadomości narodowej. Istotne znaczenie miały również inne decyzje cara - o uczynieniu języka fińskiego oficjalnym językiem administracji i wymiaru sprawiedliwości, ustanowieniu rodzimego pieniądze (rubla fińskiego), samorządu miejskiego i powszechnego szkolnictwa podstawowego $^{19}$, a także zalążka armii fińskiej w liczbie 5000 żołnierzy $(1874 \text { r.) })^{20}$. Po krótkim okresie złagodzenia kursu powróciły i wzmocniły się tendencje caratu do ograniczenia odrębności Finlandii i jej pełnego włączenia do Rosji. Manifest lutowy cara Mikołaja II z 1899 r., który faktycznie znosił odrębność prawnoustrojową Finlandii, spotkał się ze zdecydowanym oporem Finów ${ }^{21}$. Wzrost fińskiej świadomości narodowej nastąpił w sprzyjającym okresie znacznego osłabienia Rosji w następstwie wojny z Japonią. W listopadzie 1905 r. car Mikołaj II zniósł manifest lutowy i przywrócił

16 Ibidem, s. 25.

17 J. Osiński, op.cit., Warszawa 2003, s. 10.

18 Być może działania cara podyktowane były obawą przed powtórzeniem się w Finlandii scenariusza polskiego, tzn. wybuchu antyrosyjskiego powstania (T. Cieślak, Historia Finlandii, Wrocław 1983, s. 154 i n.).

19 M. Grzybowski, Finlandia. Zarys systemu ustrojowego, Kraków 2007, s. 12 .

20 S. Sagan, V. Serzhanova, op.cit., s. 27.

21 Oprócz środków pokojowych, jak petycja do cara o uchylenie manifestu podpisana przez ponad 500 tysięcy osób, uciekano się również do aktów przemocy, nawet o charakterze terrorystycznym (udany zamach na generał-gubernatora M.J. Bobrikowa) podejmowanych przez Partię Czynnego Oporu, organizację do walki z caratem i rusyfikacją (ibidem, s. 27). 
Finlandii autonomię. Zgromadzenie stanowe zwołane na 20 XII 1905 r. uchwaliło nowy Akt o Parlamencie, zatwierdzony przez cara 20 VII 1906 r. Powołano 1-izbową Eduskuntę, czyli 200-osobowy parlament, który zastąpił archaiczne zgromadzenie czterostanowe. Ordynacja wyborcza do nowego parlamentu przyznawała pełne prawa kobietom, znosiła cenzusy stanowe i majątowe oraz obniżyła próg czynnego prawa wyborczego do 24 lat. W ten sposób liczebność elektoratu zwiększyła się aż dziesięciokrotnie. W konsekwencji reprezentatywność Eduskunty znacznie wzrosła ${ }^{22}$, a w dłuższej perspektywie czasowej możliwe stało się sięgnięcie po władzę przez partię socjaldemokratyczną. Starania Finów o podporządkowanie parlamentowi władzy wykonawczej (przynajmniej Senatu jako namiastki rządu) nie powiodły się ${ }^{23}$, a car aż ośmiokrotnie w latach 1907-1917 wykorzystywał swoje uprawnienia do rozwiązania legislatywy i zarządzenia nowych wyborów. Autorytet parlamentu jednak znacznie wzrósł i stał się on organem wyrażającym aspiracje narodowe fińskiego społeczeństwa ${ }^{24}$.

Upadek caratu i objęcie władzy w Rosji przez Rząd Tymczasowy ośmieliły Finów do zgłaszania odważniejszych postulatów politycznych, przede wszystkim zwiększenia autonomii Finlandii ${ }^{25}$. Abdykacja cara Mikołaja II, jednocześnie Wielkiego Księcia Finlandii, stała się pretekstem do uchwały podjętej przez zdominowaną (102 z 200 mandatów) przez partię socjaldemokratyczną Eduskuntę o ogłoszeniu parlamentu najwyższą władzą (w miejsce cara). Ustanowiono jednak wyjątki - polityka zagraniczna, sprawy wojskowe i powoływanie składu Senatu pozostały w rękach rosyjskiego rządu $^{26}$. Rosyjski Rząd Tymczasowy nie zatwierdził tej decyzji, a nawet rozwiązał parlament. Nowy, już nie tak jednolity politycznie,

\footnotetext{
22 J. Osiński, op.cit., s. 13-14.

23 Precedens z udzieleniem wotum nieufności Senatowi i w konsekwencji jego odwołaniu przez cara nie miał podstawy prawnej innej niż wola monarchy. Wydarzenie to uchodzi jednak w literaturze za początek odpowiedzialności politycznej fińskiego rządu (zob. M. Grzybowski, Eduskunta,

24 M. Grzybowski, Eduskunta. Parlament Finlandii, Warszawa 2001, s. 9.

25 T. Cieślak, op.cit., s. 209.

26 Ibidem, s. 210.
} s. 9). 
parlament fiński zebrał się 1 XI 1917 r. ${ }^{27}$ Zamach bolszewicki i upadek Rządu Tymczasowego (8 XI) zradykalizował podział fińskiej sceny politycznej na zwolenników oderwania Finlandii od Rosji w sojuszu z Niemcami (partie mieszczańskie) i utrzymania bliskich relacji z Rosją już bolszewicką, chociaż po uprzednim ogłoszeniu niepodległości (socjaldemokraci) ${ }^{28}$.

W dniu 15 XI 1917 r. parlament po raz kolejny ogłosił się najwyższą władzą w państwie, tym razem bez wyjątków. Wybrano nowy skład rządu (tzw. Senat Niepodległości) pod kierunkiem P.E. Svinhuvfuda. Nie chcąc zwracać się do rządu bolszewickiego o zatwierdzenie decyzji parlamentu, postanowiono, że decyzję podejmie Eduskunta (Deklaracja Niepodległości, 6 XII) ${ }^{29}$. Najważniejszym zadaniem rządu stało się uzyskanie uznania niepodległości Finlandii przez inne kraje, na czele $z$ najbardziej wpływowymi. Proces ten przebiegał $z$ dużymi oporami. Jako pierwszy uznał niepodległość Finlandii rząd bolszewicki. W ślad za nim podążyły Francja, Szwecja i Niemcy (styczeń 1918 r.) ${ }^{30}$. Podjęte w styczniu działania Senatu zmierzające do utworzenia „silnej władzy porządkowej”, zaprowadzenia porządku oraz rozbrojenia i wyparcia $z$ terytorium kraju wciąż licznych oddziałów rosyjskich przerodziły się w wojnę domową. Wydarzenia roku 1917 - kryzys ekonomiczny i pogarszająca się sytuacja żywnościowa, poczucie zagrożenia, zamieszki i strajki, brak własnej armii - doprowadziły do powoływania uzbrojonych grup mających na celu zaprowadzenie porządku. To one, wspierane przez przeciwne obozy polityczne, a także wspomagane $z$ zewnątrz, głównie przez Niemców i bolszewików, były stronami krótkiego, ale krwawego konfliktu wewnętrznego. Kierowane przez umiarkowanych socjaldemokratów siły „czerwonych” nie zmierzały co prawda do wybuchu w Finlandii rewolucji bolszewickiej, ale ich zwycięstwo przy istotnym udziale Lenina doprowadziłoby do włączenia Finlandii do Związku Sowieckiego ${ }^{31}$. Siły „białych” pod dowództwem gen.

\footnotetext{
27 Ibidem, s. 212.

28 O. Jussila, S. Hentilä, J. Nevakivi, Historia polityczna Finlandii 1809-1999, Kraków 2001, s. 112.

29 M. Grzybowski, Finlandia, s. 13.

30 O. Jussila, S. Hentilä, J. Nevakivi, op.cit., s. 114-118.

31 Ibidem, s. 132.
} 
G. Mannerheima, szwedzko-fińskiego arystokraty i byłego carskiego oficera mianowanego przez Senat dowódcą sił rządowych, walczyły o niepodległość i uwolnienie Finlandii od rosyjskich wpływów. Wojna zakończyła się sukcesem „białej” Finlandii głównie za sprawą sukcesów militarnych Mannerheima, jednak nie bez znaczenia była pomoc wojskowa ze strony Niemiec. Była ona efektem niekonsultowanej z rządem inicjatywy 2 posłów do Eduskunty. Korzystna dla Niemiec $^{32}$, dla Finlandii oznaczała, poza ograniczonymi militarnymi korzyściami, wiele niekorzystnych konsekwencji o charakterze gospodarczym i politycznym. Wydarzenie to spotkało się ze sprzeciwem ze strony Mannerheima i do dzisiaj dzieli fińskich badaczy ${ }^{33}$.

Koniec wojny domowej i zwycięstwo „białych” z jednej strony stanowiły wzmocnienie dążeń niepodległościowych państwa, z drugiej - nie rozwiązywały fundamentalnych kwestii natury prawnoustrojowej. Pierwsze posiedzenie Eduskunty odbyło się przy obecności mniej niż połowy członków. Pozostali wywodzący się z socjaldemokracji, a więc partii, która przegrała wojnę, przebywali na emigracji, w więzieniach lub nie żyli. Posłów mieszczańskich podzieliła kwestia formy ustrojowej państwa - republikańskiej czy monarchicznej. Akt 15 XI 1917 r. (ustanowienie Eduskunty najwyższym organem władzy) można było interpretować jako zerwanie blisko 100-letnich więzów państwowych $z$ Rosją, a więc koniec epoki monarchicznej. Nie zmieniało to faktu, że Finlandia nie miała innego aktu ustrojowego niż monarchiczny Akt o Formie Rządu z 1772 r. (z późniejszymi modyfikacjami) i do czasu uchwalenia nowej konstytucji był on podstawą prawnoustrojową funkcjonowania państwa. Dlaczego w 1918 r. Eduskunta, decydując się na powołanie przejściowo 1-osobowego rządu, nie zdecydowała się na ustanowienie urzędu prezydenta (co byłoby kolejnym krokiem, po ustanowieniu Eduskunty najwyższym organem władzy, w kierunku nadaniu państwu formy republikańskiej), ale mianowała regenta? Powodów było kilka. Negatywne doświadczenia wojny domowej wywołały u wielu polityków partii mieszczańskiej przekonanie

32 M. Grzybowski, Finlandia, s. 14.

33 Ibidem, s. 129-130. S. Sagan, V. Serzhanova, op.cit., s. 32. 
o niedojrzałości fińskiego narodu do demokracji. Wprowadzenie powszechnego prawa wyborczego przyniosło zwycięstwo socjaldemokracji obarczanej odpowiedzialnością za wybuch wojny domowej. Rozważano ponowne ograniczenie praw wyborczych, a w trudnej sytuacji wojennej (po wojnie domowej i w trakcie konfliktu światowego) Finlandia potrzebowała silnej władzy rządzącej ${ }^{34}$.

Istotny był skład polityczny kadłubowego parlamentu zdominowany przez partię mieszczańską, w której gronie większość stanowili zwolennicy monarchii ${ }^{35}$. Wykorzystali oni przepis art. 36 Aktu o Formie Rządu, który regulował postępowanie w wypadku wygaśnięcia dynastii (co nastąpiło wraz z abdykacją cara Mikołaja II). W myśl przepisu wyboru monarchy dokonywało w takim wypadku zgromadzenie stanowe ${ }^{36}$. W okresie przejściowym szwedzka praktyka ustrojowa przewidywała powołanie tymczasowego regenta ${ }^{37}$. W efekcie kadłubowa Eduskunta ${ }^{38}$, jako następca prawny Riksdagu podjęła dwie istotne decyzje ustrojowe (15 V 1918 r.). Na stanowisko regenta, który otrzymał pełnię władzy wykonawczej w okresie przejściowym do momentu objęcia tronu przez monarchę, powołano byłego przewodniczącego Senatu P.E. Svinhuvfuda ${ }^{39}$. Parlament postanowił także o zwróceniu się do książąt niemieckich z prośbą o objęcie fińskiego tronu ${ }^{40}$. Nie bez znaczenia był tutaj aktywny udział niemieckiej dyplomacji oraz wspomnienie niemieckiej pomocy wojskowej z czasów wojny domowej ${ }^{41}$. Finlandia potrzebo-

34 O. Jussila, S. Hentilä, J. Nevakivi, op.cit., s. 137.

35 J. Osiński, op.cit., s. 19.

36 S. Sagan, V. Serzhanova, op.cit., s. 33.

37 O. Jussila, S. Hentilä, J. Nevakivi, op.cit., s. 134.

38 Fakt podjęcia tak istotnej decyzji przez niepełny parlament wzbudził protesty za granicą. Poselstwo francuskie w Sztokholmie wydało oświadczenie, że rząd francuski nie uzna żadnego reżimu wprowadzonego w sposób nielegalny, a rządy monarchiczne wprowadzono bez zachowania dostatecznego, konstytucyjnego poparcia (Telegram from the Minister to Sweden Morris to the Secretary of State Lansing, $\mathrm{nr}$ 381, Stockholm, 1 VI 1918 r., [w:] Finland 1917-1918 in the documents of the Department of State, Wrocław 2007, s. 321 ).

39 J. Osiński, op.cit., s. 18.

40 T. Cieślak, op.cit., s. 222.

41 S. Sagan, V. Serzhanova, op.cit., s. 32. 
wała sojusznika w sporze terytorialnym o Wschodnią Karelię i Petsamo ( $z$ Rosją) i widziała go w Niemczech. Svinhuvfud energicznie zabiegał o zyskanie w Niemczech akceptacji dla monarchicznych aspiracji Finlandii i uzyskanie zgody na objęcie tronu od jednego z książąt. Nie był z przekonania monarchistą, a decyzję parlamentu postrzegał w kategoriach wsparcia dla kruchej fińskiej niepodległości ${ }^{42}$.

Propozycję objęcia tronu Finlandii złożono kilku kandydatom. Najpierw synowi cesarza Niemiec Oskarowi Hohenzollernowi. Dwór cesarski odrzucił tę propozycję. Jako potencjalnych kandydatów wymieniano już wcześniej także Wielkiego Księcia Meklemburgii Adolfa Fryderyka (była to już jednak wówczas nieaktualna kandydatura, gdyż książę zmarł w lutym 1918 r.) oraz synów króla Szwecji Gustawa V: Wilhelma i Lennarta ${ }^{43}$. Ostatecznie, w sierpniu złożono ofertę 50-letniemu księciu heskiemu Fryderykowi Karolowi Ludwikowi Konstantynowi von Hessen-Kassel, który wyraził zgodę. Istotne znaczenie dla wyboru tego właśnie kandydata miał fakt jego małżeństwa z siostrą Cesarza Niemiec Małgorzatą. Eduskunta dokonała wyboru króla 9 X 1918 r. jako Karola I ${ }^{44}$ (Kaarle I). Na następcę tronu przewidziano młodszego syna Wolfganga Moritza. Finowie nie wiedzieli, że tego samego dnia USA zaakceptowało niemiecką propozycję zawieszenia broni ${ }^{45}$. Miesiąc później upadło Cesarstwo Niemiec.

W dniu 10 XII do dymisji podał się regent Svinhuvfud; 14 XII Fryderyk Karol złożył na ręce posła fińskiego w Berlinie E. Hjelta oficjalne zrzeczenie się tronu, rozumiejąc, że w ówczesnej sytuacji nie tylko nie ma mowy o objęciu tronu, ale osoba króla może okazać się dla Finlandii kłopotliwa ${ }^{46}$. Chociaż przygotowania do koronacji

42 M. Häikiö, Pehr Evind Svinhufvud (1861-1944), 100 Faces from Finland. A Biographical Kaleidoscope, http://www.kansallisbiografia.fi/kb/ artikkeli/501/ (dostęp: 28 IV 2011 r.).

43 A. Huldén, Kuningasseikkailu Suomessa 1918. Helsinki 1988, s. $47-57$.

44 Później imię to zmieniono na fińskie: Väinö I.

45 O. Jussila, S. Hentilä, J. Nevakivi, op.cit., s. 138.

46 Podczas rozmów $z$ państwami zachodnimi w listopadzie i grudniu 1918 r. G. Manneheim deklarował zerwanie przez Finlandię z opcją nie- 
były zaawansowane, król nie zdążył odwiedzić Finlandii ${ }^{47}$. Skład nowego Senatu okazał się w przeważającej mierze sprzyjający republice podobnie jak nowo powołany regent C.G. Mannerheim. Wybrana w marcu 1919 r. Eduskunta składająca się w przeważającej mierze $z$ partii lewicowych przygotowała i uchwaliła 21 VI 1919 r. nowy Akt o Formie Rządu (zatwierdzony przez regenta 17 VII). Wejście w życie tej republikańskiej konstytucji zakończyło krótki okres monarchii fińskiej. Króla i regenta zastąpił prezydent wybrany wyjątkowo przez Eduskuntę. Następni prezydenci mieli być już wybierani w powszechnych i bezpośrednich wyborach ${ }^{48}$.

III. Historia Królestwa Litwy ustanowionego w 1918 r. wykazuje wiele podobieństw do casusu Królestwa Finlandii. Również w tym wypadku proklamowanie monarchii wynikało nie (lub nie przede wszystkim) $z$ rojalistycznych przekonań, ale $z$ pragmatycznego rachunku politycznego.

Litwini, których ziemie od III rozbioru Rzeczypospolitej Obojga Narodów znajdowały się w większości we władaniu Rosji, długo nie zgłaszali roszczeń niepodległościowych. Pierwsze postulaty dotyczące autonomii pojawiły się na fali sukcesów rewolucji $1905 \mathrm{r}$. W ślad za ukazem cara Mikołaja II o zwołaniu Dumy państwowej (6 VIII) i zapowiedzi rządów konstytucyjnych (17 X) nacjonaliści litewscy na czele $z$ J. Basanavičiusem w Odezwie do narodu litewskiego proponowali zwołanie do Wilna zjazdu litewskiego w celu narady nad złożonymi potrzebami narodu, w tym kwestii autonomii dla Litwy. Entuzjastyczne przyjęcie tej propozycji zaowocowało zorganizowaniem w Wilnie w listopadzie (grudniu) 1905 r. zjazdu, na który przybyło ponad 2000 delegatów z różnych zakątków Litwy ${ }^{49}$. Przeszedł on do historii jako Sejm Wileński, a nawet Sejm Wielki ${ }^{50}$. Krótki epizod w historii niepodległościowych dążeń Litwinów zakończył się wraz ze stłumieniem rewolucji. Powrót do tej kwestii nastą-

miecką, a więc pośrednio również z monarchią (ibidem, s. 138).

47 W tym celu wykonano nawet koronę, która zachowała się do dzisiaj.

48 J. Osiński, op.cit., s. 19.

49 J. Ochmański, Historia Litwy, Wrocław 1982, s. 260.

50 H. Wisner, Litwa. Dzieje państwa i narodu, Warszawa 1999, s. 148-149 . 
pił po wybuchu I wojny światowej, która ujawniła istnienie kilku orientacji politycznych $\mathrm{w}$ gronie litewskich działaczy niepodległościowych. O ile tzw. grupa bursztynowa stawiała na opcję prorosyjską, upatrując sukcesu sprawy litewskiej w zwycięstwie Rosji, o tyle „autonomiści” odrzucali ugodę $z$ caratem na rzecz samodzielnej walki o uzyskanie dla Litwy niepodległości po zjednoczeniu jej wszystkich ziem etnicznych (podzielonych wówczas wciąż między zaborców). W 1914 r. posłowie litewscy do Dumy utworzyli jedną organizację w miejsce dotychczasowych stronnictw autonomicznego i bursztynowego. Opanowanie większości ziem litewskich przez Niemców w 1915 r. otworzyło zupełnie nowy rozdział w historii dążeń niepodległościowych Litwinów. Opcja prorosyjska stała się nieuaktualna. Chociaż początkowo władze Rzeszy nie miały ani sprecyzowanego stanowiska co do przyszłości, ani orientacji w bieżącej sytuacji politycznej Litwy ${ }^{51}$, kwestia litewska stała się wkrótce jednym $z$ głównym elementów polityki niemieckiej. Na terenach okupowanych państw bałtyckich ustanowiono tymczasowy wojskowy zarząd, tzw. Oberkommando-Ost ${ }^{52}$.

Na pierwsze konkretne deklaracje ze strony niemieckiej należało czekać aż do roku 1917. Lata 1915-1916 upłynęły pod znakiem bezlitosnej eksploatacji terenów litewskich oraz likwidacji wszystkich organizacji społecznych, politycznych oraz czasopism w języku litewskim ${ }^{53}$. Skala spustoszeń była ogromna. Biuro Litewskie

51 P. Kierończyk, System konstytucyjny państwa litewskiego (1922-1940), Gdańsk 2008, s. 21.

52 Pełna nazwa: Oberbefehlshabersost - Naczelne Dowództwo Wschodu. Od marca 1917 r. w ramach Ober-ostu na terenach litewskich utworzono Militarverwaltung Litauen pod dowództwem ks. Franza von Isenburg-Birstein (J. Ochmański, op.cit., s. 276-277).

53 Sugestywną charakterystykę stosunku Niemców do terytorium i ludności Litwy odnaleźć można we wspomnieniach gen. E. Ludendorffa. Za główne zadanie Niemców na tych terenach uznał szerzenie kultury, ,jak Niemcy czynili przez stulecia”. Ludność miejscową określał jako „grupę różnych zwaśnionych plemion” nieprzychylnych Niemcom (z wyjątkiem miejscowych Niemców bałtyckich), przy czym Litwini wykazywali się biernością, a Polacy skrajną wrogością (E. Ludendorff Meine Kriegserinnerungen 1914-1918, Berlin 1920, s. 138-139, 148). 
w Lozannie informowało, że w początku 1917 r. na Litwie było 150 tys. bezdomnych i głodujących cywilów, 400 tys. zdewastowanych gospodarstw, a śmiertelność wzrastała w alarmującym tempie z powodu rażąco niskich warunków sanitarnych ${ }^{54}$. Niemcy wciąż wahali się pomiędzy kolonizacją Litwy jako części tzw. Mitteleuropy a stworzeniem na Litwie państwa autonomicznego, ściśle związanego z Rzeszą - wobec braku wiary w możliwość pełnego sukcesu akcji germanizacyjnej narodów bałtyckich ${ }^{55}$. Bodźcem dla litewskich działaczy niepodległościowych był Akt 5 listopada 1916 r. ogłoszony przez Niemcy i Austrię, zapowiadający utworzenie Królestwa Polskiego. Jurgis Šaulys i Antanas Smetona podjęli natychmiast próbę wysondowania niemieckiego sekretarza stanu A. Zimmermanna. Dopiero w lipcu następnego roku nadeszła odpowiedź - Zimmermann publicznie wypowiedział się o projekcie unii personalnej między Niemcami, Litwą i Kurlandią. Rewolucja w Rosji zaktywizowała stronę niemiecką do działania. W ślad za deklaracją gen. Ludendorffa z 30 V 1917 r. zezwalającej na utworzenie czysto litewskiej rady przedstawicieli ${ }^{56}$ we wrześniu zebrała się w Wilnie tzw. Konferencja litewska, która dokonała wyboru 20-osobowej Rady Litewskiej (Lietuvos Krasto Taryba), zwanej w skrócie Tarybą. $\mathrm{Na}$ jej czele stanął A. Smetona ${ }^{57}$. Konieczne dla litewskich dążeń niepodległościowych przyzwolenie Niemiec, nieoczywiste wobec deklarowanych i popularnych planów aneksji terenów litewskich do Rzeszy, tłumaczy się chęcią uniknięcia przez Niemców wybuchu konfliktu polsko-litewskiego. Po proklamowaniu Królestwa Polskiego w listopadzie 1916 r., Litwini zasługiwali na jakiś przyjazny gest ze strony Niemiec ${ }^{58}$. Strona litewska zdawała sobie $z$ kolei

54 S.W. Page, The formation of the Baltic States. A study of Great Power Politics upon the Emergence of Lithuania, Latvia and Estonia, Cambridge 1959, s. 29.

55 J. Ochmański, op.cit., s. 278-279.

56 Ibidem, s. 280-282.

57 P. Kierończyk, op.cit., s. 26.

58 Ze wspomnień E. Ludendorffa wiemy jednak, że krótko po ogłoszeniu Aktu 5 listopada Litwini otrzymali za pośrednictwem Sekretarza Stanu G. von Jagow notyfikację dającą „zielone światło” dla ich niepodległościowych dążeń (E. Ludendorff, op.cit., s. 374). 
sprawę, że uzyskanie niepodległości jest w ówczesnej sytuacji politycznej możliwe wyłącznie $z$ pomocą Niemiec. To za sprawą niemieckiej okupacji wszystkie etnograficzne i historyczne tereny litewskie, z których usunięto Rosjan, znalazły się w jednym, niemieckim władaniu i od decyzji Niemiec zależał ich przyszły $\operatorname{los}^{59} . Z$ drugiej strony relna wciąż pozostawała groźba włączenia terenów litewskich do Rzeszy. Sytuacja wymagała od Litwinów rozważnego działania. Członkowie litewskiej diaspory na zachodzie Europy i w USA wykazywali zwielokrotnioną aktywność, zabiegając o nadanie sprawie litewskiej rangi międzynarodowej. W jednym $z$ dwóch artykułów manifestu wydanego przez Tarybę zadeklarowano przyjazne związki Litwy z Niemcami, ale pod warunkiem uznania przez Niemcy niepodległego państwa litewskiego ${ }^{60}$. Temu celowi podporządkowano wszystkie działania.

Chociaż Taryba została przez Litwinów również poza granicami kraju uznana za „najwyższą instancję dla całego narodu litewskiego i dla wszystkich jego organizacji”" ${ }^{61}$, nie miała żadnych władczych uprawnień, a więc żadnego, poza symbolicznym, znaczenia. Litwini boleśnie przekonali się o tym, kiedy na fali zwycięstwa rewolucji październikowej w Rosji oraz następujących po sobie deklaracji rosyjskiej i niemieckiej o prawie do samostanowienia narodów dawnej Rosji przystąpili do rozmów z Niemcami w Berlinie, w grudniu 1917 r. Gdy w myśl osiągniętego porozumienia Taryba proklamowała 11 XII 1917 r. niepodległość Litwy, akt ten nie został uznany przez rząd niemiecki ${ }^{62}$, chociaż znalazły się w nim sformułowania dotyczące „wiecznego, mocnego stosunku związkowego państwa litewskiego z Cesarstwem Niemieckim"63. Reakcją, określaną jako efekt rozdrażnienia czy nawet frustracji członków Taryby ${ }^{64}$, było powtórne ogłoszenie niepodległości Litwy

59 S.W. Page, op.cit., s. 31-32.

60 Ibidem, s. 30-31.

61 J. Ochmański, op.cit., s. 282.

62 P. Kierończyk, op.cit., s. 29.

63 J. Ochmański, op.cit., s. 284. W akcie protestu przeciwko tak dalekim ustępstwom wobec Niemiec kilku członków Tarybie opuściło jej skład.

64 Ibidem, s. 284, P. Kierończyk, op.cit., s. 29. 
(16 II 1918 r.), tym razem opartej na „demokratycznych podstawach, ze stolicą w Wilnie i odrzuceniem wszelkich państwowych związków, które były ustanowione $z$ innymi narodami”. Pominięto więc deklarację o „wiecznym i mocnym związku” z Niemcami. Akt ten, jakkolwiek ryzykowny i sprawiający wrażenie desperackiego, był $\mathrm{w}$ istocie doskonale przemyślanym zagraniem politycznym Litwinów. Należy pamiętać, że dobiegały końca rozmowy niemiecko-rosyjskie, które doprowadzić miały do podpisania traktatu w Brześciu Litewskim. Karta litewska odgrywała w tej rozgrywce niebagatelną rolę jako jeden $z$ atutów niemieckich. Jego utrata nie była dla Niemców korzystna ${ }^{65}$. Litwini zagrali więc kartą swojej niepodległości w odpowiednim, ostatnim momencie. Odpowiedź niemieckich władz była natychmiastowa ${ }^{66}$. Rzesza Niemiecka w osobie kanclerza Georga von Hertlinga deklarowała gotowość uznania niepodległej Litwy, ale na warunkach określonych w pierwszym akcie niepodległości z 11 XII 1917 r. Delegaci Taryby niezwłocznie zapewnili stronę niemiecką o woli związku z Rzeszą, wzmacniając swoje oświadczenie dziękczynnym telegramem adresowanym do Cesarza Wilhelma $\mathrm{II}^{67}$.

Litwini nie znali w pełni kulisów niemieckiej polityki wschodniej. Zarówno brak reakcji na pierwszą deklarację niepodległości, jak i niejednolita polityka ustępstw i zaostrzeń kursu wobec Litwy wynikały ze skomplikowanej sytuacji politycznej wewnątrz Niemiec i braku zgody co do przyszłości terytoriów wschodnich. Niemcy, pomimo formalnego zjednoczenia, nadal stanowiły konglomerat rozbieżnych, partykularnych interesów i dążeń. Decyzja o aneksji

65 Więcej o przebiegu i kulisach tej rozgrywki zob. S.W. Page, op.cit., s. $44-54$.

66 Skonfiskowano cały nakład pisma „Lietuvos Aidas”, w którym ogłoszono nową wersję Deklaracji Niepodległości (A. Eidintas, Restoration of the State, [w:] A. Eidintas, V. Žalys, E. Tuskenis, Lithuania in European Politics: The Years of the First Republic, 1918-1940, New York 1999, s. 30).

67 J. Ochmański, op.cit., s. 285. Ta decyzja postawiła „Tarybę” w dwuznacznej sytuacji. Na wieść o treści drugiej deklaracji niepodległości do jej szeregów powrócili polityce, którzy uprzednio podali się dymisji. Powrót do dawnej, proniemieckiej deklaracji mogli odebrać jako afront, co groziło konfliktem w łonie Taryby (S.W. Page, op.cit., s. 53-54). 
Litwy, zgodna z poglądami przeważającymi w Reichstagu oraz panującymi wojennymi nastrojami, wymagała jednak precyzyjnych ustaleń dotyczących politycznego kształtu litewskiej prowincji. Osadzenie na tronie Litwy Hohenzollerna wzmacniałoby pozycję Prus w ramach Cesarstwa, co wzbudziło sprzeciw władców Saksonii i Bawarii ${ }^{6}$. Wszelkie terytorialne modyfikacje w granicach Rzeszy zaburzały $z$ trudem uzyskaną równowagę i groziły powrotem kwestii dotąd nierozstrzygniętych, jak np. ewentualny podział Alzacji i Lotaryngii (przyłączonych do Rzeszy w wyniku zwycięskiej wojny z Francją) między Bawarię, Badenię i inne państwa niemieckie ${ }^{69}$.

Podpisanie traktatu brzeskiego $z$ Rosją, a także zwycięstwa militarne z lutego 1918 r., które powiększyły terytoria niemieckie o obszar Liwonii i Estonii, wzmocniły pozycję zasiadających we władzach niemieckich zwolenników pełnej aneksji terenów wschodnich do Rzeszy, na czele $z$ samym cesarzem ${ }^{70}$. W tej sytuacji oficjalne wystąpienie króla Saksonii, który domagał się korony litewskiej dla swojego syna Fryderyka Augusta III, powołując się m.in. na historyczne tradycje, pozostało bez echa ${ }^{71}$. Sytuacja przyjęła zły dla Litwinów obrót. Sprawa przyszłości Litwy rozgrywała się bez ich udziału.

Nagły zwrot przyniosła inicjatywa M. Erzbergera, posła Partii Centrum (Deutsche Zentrumspartei) i stronnika spraw litewskich, który zgłosił propozycję osadzenia na tronie Litwy księcia Wilhelma von Urach, Grafa von Württemberg ${ }^{72}$. Sprzeciw wobec tej kandydatury zjednoczył obóz aneksjonistów, chociaż pozostał on podzielony na zwolenników Hohenzollernów i Wettynów. Ostatecznie ustalono kompromisowe rozwiązanie. Hohenzollernowie mieli objąć w pano-

68 A.E. Senn, The emergence of modern Lithuania, Westport 1975, s. 36.

69 S.W. Page, op.cit., s. 50-51.

70 Cesarz Wilhelm po podpisaniu traktatu brzeskiego oświadczył, że „Balticum jest całością, a ja będę jego władcą i nie będę tolerował żadnego sprzeciwu. Zdobyłem je i żaden prawnik mi go nie odbierze. Balticum jako całość pozostanie w unii personalnej pod rządami króla Prus, który je zdobył. Tak jak za Frydedyka Wielkiego!” (za: H.H. Herwig, German Policy in the Eastern Baltic Sea in 1918: Expansion or Anti-Bolshevik Crusade?, Slavic Review 1973, t. 32, nr 2, s. 341).

71 A.E. Senn, op.cit., s. 36-37.

72 A. Eidintas, Restoratio, s. 30-31. 
wanie Kurlandię, Liwonię i Estonię, a koronę litewską cesarz obiecał Wettynom ${ }^{73}$. Saksonię i Litwę miała połączyć unia personalna. W dniu 8 marca Landesrat Kurlandii zebrany w Rydze wystosował adres do Cesarza Wilhelma II, wyrażając nadzieję na przyjęcie przezeń korony Księstwa Kurlandii i przyłączenie go do Rzeszy ${ }^{74}$.

Sytuacja wymagała szybkiej reakcji ze strony Litwinów. Plany budowy republiki litewskiej w oparciu o demokratycznie wybrany parlament, zadeklarowane uprzednio przez Sejm Wielk i Tarybę, należało odłożyć. Opcja monarchiczna wydawała się obecnie bezalternatywna, podobnie jak wybór monarchy niemieckiego pochodzenia.

Wilhelm miał dwie cechy odróżniające go od konkurentów, które zdecydowały o poparciu przez Litwinów właśnie tej kandydatury. Po pierwsze był katolikiem. Silnego przywiązania do katolicyzmu (wyznania dominującego wśród Litwinów) dowodzi list hołdowniczy, który po uzyskaniu i potwierdzeniu propozycji objęcia litewskiego tronu (lipiec 1918 r.) Wilhelm wystosował do papieża, określając Litwę jako kraj w większości katolicki, a siebie i swoją rodzinę jako „wiernych świętemu kościołowi katolickiemu”75. Po drugie za sprawą morganatycznego małżeństwa jego dziadka ${ }^{76}$ nie miał praw do tronu Królestwa Wirtembergii ${ }^{77}$. Zabezpieczało to Litwę przed marginalizacją, a wręcz aneksją do Niemiec, grożącą w przypadku unii personalnej zawartej przez jednego $z$ władców dziedzicznych monarchii w ramach Rzeszy. Wilhelm miał więcej zalet. Był doświadczonym żołnierzem (dowodził m.in. 26 dywizją piechoty, której szlak bojowy

73 S.W. Page, op.cit., s. 92.

74 Ibidem, s. 55.

75 S. von Cube, Ein württembergischer Prinz auf dem Thorn von Litauen, 1918, Annaberger Annalen Jahrbuch über Litauen und deutsch-litauische Beziehungen 2000, nr 8, s. 118.

76 Dziadek Wilhelma von Urach, książe Wilhelm Fryderyk von Württemberg (1761-1830), młodszy brat Fryderyka - pierwszego króla Wirtembergii, ożenił się $z$ damą dworu swojej matki, baronówną Wilhelminą von Tunderfeld-Rhodis (1777-1822). Ich potomkowie nie posiadali praw do tronu Królestwa Wirtembergii. Jako syna księżniczki Florestiny Grimaldi, córki księcia Monako miał natomiast Wilhelm von Urach prawa do tronu Księstwa Monako.

77 A.E. Senn, op.cit., s. 36, S.W. Page, op.cit., s. 51, 91. 
przebiegał od Polski przez Bałkany po Francję). Wojnę ukończył w randze generała. Na Uniwersytecie w Tybindze studiował geografię ${ }^{78}$. Po trzecie obawy przed ewentualnym późniejszym porozumieniem się Wilhelma $z$ Cesarzem, ponad głowami i wbrew woli Litwinów, zmniejszał fakt chłodu, jaki panował w relacjach Urachów z Hohenzollernami. Jego powodem było niedoszłe do skutku z powodów religijnych małżeństwo Joachima von Preussen (młodszego syna cesarza) $z$ Elżbietą von Urach ${ }^{79}$. Wreszcie Wilhelm nie przejawiał zainteresowania współpracą $z$ Polakami, co stanowiło dla Litwinów bardzo ważny argument ${ }^{80}$. Warto przy tej okazji wspomnieć, że książę von Urach nie był jedynym kandydatem do tronu zgłaszanym przez samych Litwinów. Członkowie litewskiej diaspory w Szwajcarii wysunęli kandydaturę następcy tronu hiszpańskiego Alfonsa Burbona ${ }^{81}$.

Wstępna decyzja w sprawie poparcia dla kandydatury Wilhelma von Urach, a więc tym samym w sprawie ustanowienia monarchii nie była pierwsza. W dniu 8 XII 1917 r. Taryba oficjalnie opowiedziała się za monarchią jako optymalną formą rządów przyszłego państwa litewskiego ${ }^{82}$. Nie była to jednak decyzja, a jedynie opinia Rady. Taką jej interpretację przyjęto w efekcie sprzeciwu kilku członków Taryby. Prawo do wiążącego wyboru formy rządów przekazano wówczas przyszłemu sejmowi ${ }^{83}$.

Tym razem (III-IV 1918 r.) Taryba uznała się za uprawnioną do podjęcia decyzji. Trzech jej członków, na znak protestu, opuściło

78 S. von Cube, op.cit., s. 115.

79 Ibidem, s. 117.

80 J. Skirius, Vokietija ir Lietuvos nepriklausomybe, http://mkp.emokykla.lt/gimtoji/index.php?id=1173 (dostęp: 27 VI 2011).

81 J. Wisner, op.cit., s. 164.

82 Uchwała stwierdzała: „w obecnej sytuacji i przy panujących okolicznościach dla przyszłego państwa litewskiego najbardziej odpowiednią jest dziedziczna monarchia konstytucyjna, mianowicie Królestwo, zarządzane w demokratyczny, parlamentarny sposób, na czele z przedstawicielami katolickiej dynastii” (za: A. Pukszto, Między stołecznościa a partykularyzmem. Wielonarodowościowe społeczeństwo Wilna w latach 1915-1920, Toruń 2006, s. 87).

83 Uznano, że na tym etapie monarcha będzie lepszy niż prezydent, który nie zdobędzie w społeczeństwie litewskim należnego autorytetu (J. Wisner, 
szeregi rady. Pozostali uznali, że ówczesna, nadzwyczajna sytuacja (realne zagrożenie unią z Saksonią lub aneksją do Rzeszy) wymaga i pozwala na działania nadzwyczajne ${ }^{84}$.

Delegacja Taryby zamierzała zaprezentować swoje stanowisko w Berlinie, a także spotkać się z księciem Wilhelmem ${ }^{85}$. Władze niemieckie grały na zwłokę. Wniosek o pozwolenie na wyjazd złożony przez litewską delegację w kwietniu 1918 r. czekał na rozpatrzenie do czerwca. Kanclerz nie znalazł czasu na spotkanie z członkami Taryby ${ }^{86}$. W tej sytuacji Taryba przyjęła taktykę faktów dokonanych. Dnia 4 VI oficjalnie wybrała Wilhelma von Urach jako kandydata na króla litewskiego Mendoga II ${ }^{87}$.

Na tym samym, tajnym posiedzeniu Prezydium Taryby opracowano wykaz warunków, swoistych pacta conventa ${ }^{88}$, od których przyjęcia przez księcia uzależniano jego ostateczny wybór na króla Litwy.

W dniu 1 VII 1918 r. przedstawiciele Taryby spotkali się z Wilhelmem von Urach we Fryburgu Bryzgowijskim. Po negocjacjach, tego samego dnia Wilhelm przyjął propozycję objęcia tronu. Dnia 9 VII podobną deklaracją złożył Wilhelm Albert jako przyszły

op.cit., s. 161). Decyzja zapadła wówczas większością 15 głosów przeciw 5 (M. Maksimaitis, Lietuvos valstybès konstituciju istorija - XX a. pirmoji pusé, Wilnius 2005, s. 45-46).

84 S.W. Page, op.cit., s. 93.

85 Wilhelm już podjął pierwsze kroki. Dnia 7 marca zwrócił się do króla Wirtembergii Wilhelma II, informując o planach objęcia tronu Litwy i pytając o zgodę. Król opowiedział się przeciwko tym planom, ale jednocześnie zapowiedział, że nie będzie czynnie występował przeciw ich realizacji, czy samemu von Urachowi (M. Peleckis, T. Baranauskas, Karališkojo kraujo paieškos: Lietuva ir šimto dienų karalius, na stronie: Interneto dienrašti „Bernardinai.1t“ (dostęp 24 X 2006), S. von Cube, op.cit., s. 117.

86 S.W. Page, op.cit., s. 93-94.

87 Podjęcie decyzji poprzedziło przedstawienie kandydata w pozytywnym świetle przez J. Purickisa, który spotkał się z księciem kilka dni wcześniej (J. Wisner, op.cit., s. 164).

88 A. Janužytè, Lietuvių istoriku politiku valstybingumo samprata (1907-1918 m.), Istorija. Lietuvos aukštujų mokyklų mokslo darbai 2007, nr 65, s. 19. 
następca tronu ${ }^{89}$. Obaj złożyli podpisy pod wykazem warunków przedstawionych im przez stronę litewską.

Lista składała się z 12 punktów (pkt 3 podzielony był na 6 podpunktów). We wstępie zastrzeżono, że tron litewski obejmie Wilhelm von Urach, książę Wirtemberski, a po nim jego męscy potomkowie. Pierwszy warunek stanowił, że Litwa będzie monarchią konstytucyjną $z$ zachowaniem zasad demokratycznych (pkt 1). Przyszłą pełną konstytucję Królestwa Litwy miał opracować wspólnie król oraz Taryba (pkt 2). Władza w państwie należeć miała do króla oraz narodu wykonującego swoje uprawnienia przez pochodzące $z$ wyboru organy (pkt 3). Parlament składać się miał z izby niższej Seimasu, i wyższej - Taryby (pkt 3c). Władza ustawodawcza należeć miała do parlamentu i króla, władza wykonawcza do ministrów powoływanych przez króla i pozostających pod kontrolą Seimasu (pkt 3a-b). Każdy akt prawny wymagał dla swojej ważności uchwalenia przez parlament i zatwierdzenia przez króla (pkt 3d). Inicjatywa ustawodawcza w zakresie zmiany konstytucji należała do króla lub większości Seimasu (pkt 3e). Prawo zwykłej inicjatywy ustawodawczej - do króla, ministra, 15 członków Seimasu lub członka Taryby (pkt 3f). Konstytucja miała podlegać nie rzadziej niż raz na 10 lat rewizji (pkt 3f). Do obowiązków króla zaliczono stanie na straży konstytucji, niepodległości i niepodzielności terytorium Litwy (pkt 4) oraz tolerancji religijnej (pkt 6). Nominacje królewskie dotyczące urzędników, na czele $z$ premierem, winny obejmować wyłącznie osoby narodowości litewskiej, posługujące się językiem litewskim w mowie i piśmie (pkt 5). Król musiał uzyskać zgodę parlamentu na objęcie rządów w innym państwie (pkt 7), a także miał wraz z całą rodziną zamieszkać na Litwie. Opuszczenie jej terytorium na dłużej niż dwa miesiące w roku wymagało zgody parlamentu (pkt 8). Język litewski miał być nie tylko językiem urzędowym, ale także językiem używanym na dworze królewskim (pkt 9). $Z$ tego powodu wszyscy dworzanie mieli władać tym językiem. W 5-letnim okresie przejściowym dopuszczano obecność

89 Lietuvos konstituciju projektai 1916-1918 metais, oprac. A. Grigaravičius, [w:] Lietuviu atgimimo istorijos studijos, t. 3: Lietuvos valstybes ideja (XIX a. - XX a. pradžia), Vilnius 1991, s. 395. 
cudzoziemców niewładających językiem litewskim w szeregach dworzan; ich liczba nie mogła przekroczyć 1/3 ogólnego składu osobowego (pkt 10). Dzieci królewskie winny odbywać edukację na terenie Litwy. Zagraniczne wyjazdy edukacyjne dopuszczono wyłącznie, jeśli odpowiedniego wykształcenia nie można zdobyć na Litwie (pkt 11). Ostatni punkt dotyczył „listy cywilnej”, a więc kwoty dofinansowania $z$ budżetu państwa wydatków króla. Prawo do określania ich wysokości przysługiwać miało parlamentowi ${ }^{90}$.

Pacta conventa stały się podstawą dla regulacji zawartych w projekcie pierwszej konstytucji odrodzonego państwa litewskiego. Do prac nad jej przygotowaniem przystąpiono niezwłocznie. Ostatecznie nigdy nie weszła ona w życie - pierwszym nowożytnym, litewskim aktem ustrojowym stała się więc nie monarchiczna, ale republikańska konstytucja z 2 XI 1918 r.

Zachowały się dwa egzemplarze projektu konstytucji królestwa Litwy - w języku litewskim i niemieckim, nieznacznie różniące się treścią ${ }^{91}$. Warto podać ich wybrane postanowienia, szczególnie te dotyczące osoby i pozycji ustrojowej monarchy, zwłasza że nie były one dotąd omawiane w polskiej literaturze.

W projekcie liczącym aż 108 artykułów królowi poświęcono tytuł 2 (O królu i jego ministrach) sekcji 3 (O władzy ustawodawczej $i$ wykonawczej), a także pojedyncze artykuły w innych częściach aktu. Wiele $z$ tych przepisów powiela rozwiązania przyjęte w pacta conventa, doprecyzowuje je, ale także częściowo zmienia. W części ogólnej sekcji 3 stwierdza się m.in., że pełnia władzy wykonawczej należy do króla ${ }^{92}$, co stanowi wzmocnienie jego władzy w porównaniu z pacta conventa, gdzie władza ta podzielona była między króla i ministrów.

90 Lietuvos Centrinis Valstybės Archyvas (Litewskie Centralne Archiwum Państwowe w Wilnie, Litwa), dalej: LCVA, fond 383, ap. 7, b. 28, karty 1-1a.

91 Zgłaszane w literaturze hipotezy dotyczące autorstwa projektu przytacza A. Grigaravičius (Lietuvos konstituciju projektai, s. 391-393).

92 Art. 29 Verfassungsurkunde fuer den Litauischen Staat - maszynopis, (LCVA, f. 383, ap. 3, b. 5, k. 71-81), zwane dalej: VLS oraz art. 29 Lietuvos valstybès Konstitucija (Lietuvos konstituciju projektai..., s. 396-434), zwane dalej: LVK. 
Pierwszy artykuł tytułu 2 określa osobę pierwszego króla Litwy, wymieniając jego pełne imiona: Mindaugas II Wilhelm Karl Florestan Gero Crescentius ${ }^{93}$. Stolicą państwa i miejscem rezydowania króla konstytucja ustanawiała Wilno ${ }^{94}$. Tron litewski miał podlegać dziedziczeniu zgodnie $z$ zasadami primogenitury, wyłącznie przez potomków urodzonych $z$ małżeństwa, na którego zawarcie zgodę wyraził monarcha i obie izby parlamentu. Zawarcie małżeństwa bez uzyskania zgody lub wbrew zgodzie oznaczało utratę praw do tronu zarówno dla pretendenta do tronu, jak i jego potomków oraz wykluczenie $z$ rodziny królewskiej ${ }^{95}$. Po objęciu urzędu król miał obowiązek złożenia przed parlamentem przysięgi, której tekst zawierała konstytucja ${ }^{96}$. Objęcie przez monarchę litewskiego tronu innego państwa wymagało zgody udzielonej większością 2/3 głosów każdej $z$ izb parlamentu, pod groźbą utraty praw do tronu Litwy ${ }^{97}$. Król był politycznie nieodpowiedzialny. Odpowiedzialność polityczną za jego decyzje ponosili ministrowie kontrasygnujący akty monarchy ${ }^{98}$. Król miał prawo powoływania i odwoływania ministrów, a także określonych urzędników państwowych, którzy mieli obowiązek złożyć przed nim przysięgę wierności i posłuszeństwa oraz przestrzegać konstytucję ${ }^{99}$. Król wypowiadał wojnę, zawierał pokój oraz umowy z państwami obcymi. Decyzje te wymagały zatwierdzenia przez parlament. Ponadto ewentualny tajny aneks do traktatu pokojowego nie mógł stać w sprzeczności $z$ jego jawną częścią ${ }^{100}$. Król miał prawo bicia monety ${ }^{101}$, prawo łaski ${ }^{102}$. W przypadku prawa nadawania orderów, odznaczeń, tytułów i innych zaszczytów król nie uzasadniał swojej decyzji ${ }^{103}$. Otwierał i zamykał obrady parlamentu; za

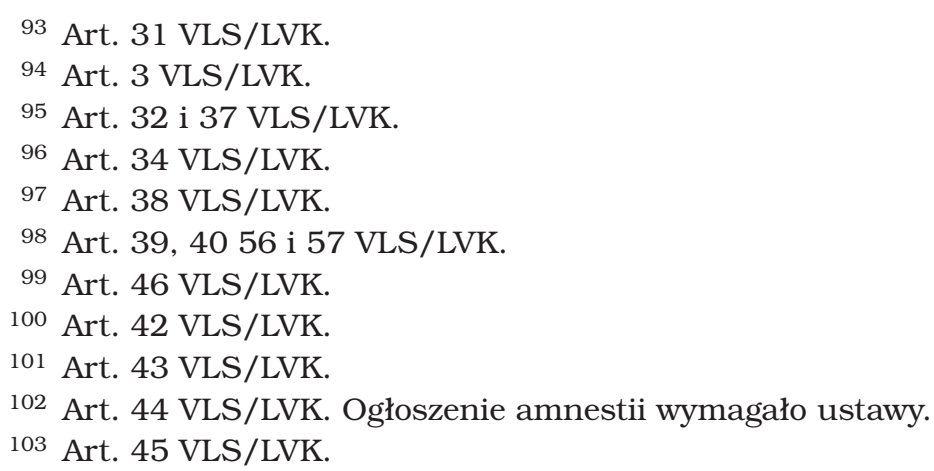


zgodą Taryby mógł odroczyć obrady Seimasu, a także rozwiązać Seimas. Wówczas miał obowiązek zarządzić nowe wybory ${ }^{104}$. Organizację wewnętrzną dworu i rodziny królewskiej powierzano wewnętrznym regulacjom domu panującego ${ }^{105}$.

Konstytucja szczegółowo regulowała wypadki zastępstwa króla. O ile krótkotrwała niemożność pełnienia urzędu przez króla dawała mu prawo do wyznaczenia tymczasowego zastępcy, o tyle długotrwała lub zupełna niemożność, względnie brak pełnoletniego następcy oznaczały nastanie regencji. Regenta mógł wyznaczyć sam król lub w przypadku braku tej decyzji - połączone izby parlamentu, przed którymi regent składał przysięgę. Władzę wykonywał w imieniu króla. Nie miał prawa kreowania nowych urzędów ani orderów. Jeśli z powodów psychicznej lub fizycznej choroby króla regencja trwałaby ponad 10 lat, decyzją obu izb parlamentu podjętą większością $2 / 3$ głosów można było opróżnić tron ${ }^{106}$.

W wypadku wygaśnięcia rodziny królewskiej nowego króla (dynastię) wybierał parlament, a w związanym $z$ tym okresie przejściowym można było ogłosić regencję ${ }^{107}$.

Oryginalny skład miała mieć Taryba - wyższa izby parlamentu. Oprócz 12 członków wybieranych przez Seimas i dwóch przedstawicieli uniwersytetu wileńskiego wybranych przez profesorów, w jej skład wchodzić mieli wiryliści: pełnoletni następcy tronu (którzy ukończyli 24. rok życia ${ }^{108}$ ), pozostali książęta należący do domu panującego (po ukończeniu 30. roku życia), biskupi rzymskokatoliccy i grekokatoliccy, prezes Sądu Najwyższego. Król miał prawo usunąć księcia $z$ Taryby ${ }^{109}$.

Dnia 11 lipca Rada Państwa dokonała wyboru Mendoga II na króla Litwy i wezwała go do objęcia tronu zgodnie $z$ uzgodnionymi we Fryburgu warunkami ${ }^{110}$. Taryba ogłosiła się Litewską Radą

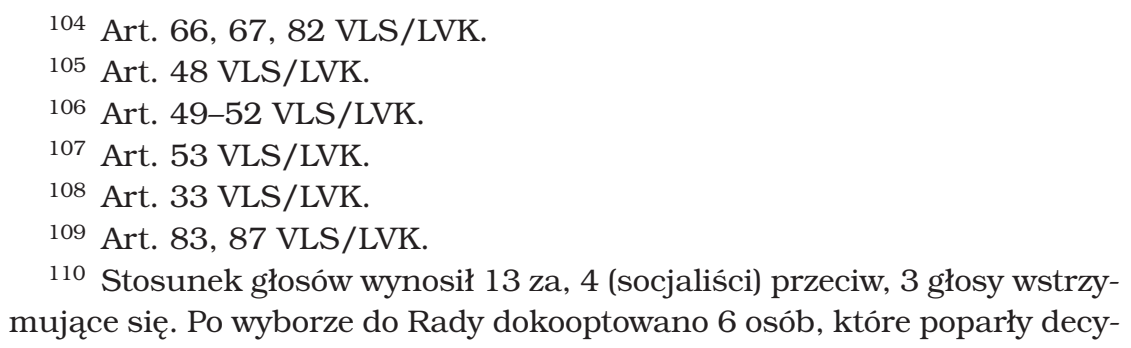

110 Stosunek głosów wynosił 13 za, 4 (socjaliści) przeciw, 3 głosy wstrzymujące się. Po wyborze do Rady dokooptowano 6 osób, które poparły decy- 
Państwa (11 VII) ${ }^{111}$. Było to działanie nielegalne, początkowo zupełnie zignorowane przez władze niemieckie ${ }^{112}$. W nocie datowanej na 25 lipca kanclerz Hertling odmawiał Tarybie uznania jako Radzie Państwa. Kwestię ustanowionego ustroju i osoby monarchy pominął milczeniem ${ }^{113}$. Jednocześnie Niemcy podjęli działania o charakterze propagandowym. W prasie niemieckiej skrytykowano decyzję Rady, odmawiając jej podstaw prawnych ${ }^{114}$. Prasa litewska otrzymała zakaz publikacji informacji na temat wyboru króla ${ }^{115}$. Decyzja o wyborze króla i jej nieuznanie przez stronę niemiecką znacznie osłabiło autorytet Rady, ukazywanej w prasie litewskiej i niemieckiej jako marionetkowe proniemieckie ugrupowanie ${ }^{116}$.

zję, a rezygnację złożyły 3 osoby w akcie protestu. W efekcie wynik głosowania to 19 głosów za i 4 przeciw. Wielu autorów podaje błędną datę: 13 VII. Błąd pochodzi $z$ listu, jaki Rada Państwa wystosowała do hrabiego Hertlinga, Kanclerza Rzeszy, datowanego na 20 VII. W tekście pojawia się informacja, że wybór księcia von Urach na króla Litwy nastąpił 13 VII. $\mathrm{W}$ liście wystosowanym do samego księcia, a także $\mathrm{w}$ protokole $\mathrm{z}$ obrad Rady widnieje poprawna data - 11 VII (S. von Cube, op.cit., s. 118). Różnica $\mathrm{w}$ dacie związana może być $\mathrm{z}$ faktem dokooptowania nowych członków Rady i ich uznania $(5$ z 6 ) decyzji o wyborze króla. Nastąpiło to właśnie 13 VII (M. Maksimaitis, Apie dvilypę valstybès tarybos prezidiumo padètí 1918 metu Lietuvos laikinojoje konstitucijoje, Jurisprudencija 2006, nr 2 (116), s. 11).

111 J. Wisner, op.cit., 134; M. Peleckis, T. Baranauskas, op.cit.; J. Ochmański (op.cit., s. 286) i P. Kierończyk (op.cit., s. 30) podają błędną datę 11 czerwca.

112 Kilkukrotne próby uzyskania zatwierdzenia decyzji Taryby jako Rady Państwa podejmowane $\mathrm{w}$ formie listów kierowanych do władz niemieckich nie przyniosły rezultatu. Listy zwracano bez otwierania $z$ adnotacją o nielegalnym tytule używanym przez nadawcę. (S.W. Page, op.cit., s. 94).

113 J. Ochmański, op.cit., s. 286.

114 Niepodległość Litwy opierała się w opinii Niemców na Akcie 11 XII i ich uznaniu, dlatego Litwini nie mieli prawa do samodzielnego (bez akceptacji Niemiec) wyboru monarchy (A.E. Senn, op.cit., s. 37).

115 Kiedy pismo „Lietuvos Aidas” (Echo Litwy) zlekceważyło nakaz opublikowania informacji zostało karnie zamknięte na miesiąc (V.G. Liulevicus, War land on the Eastern Front: culture, national identity and German Occupation in World War I, Cambridge 2000, s. 210).

116 M. Peleckis, T. Baranauskas, op.cit. 
Na zmianę nastawienia Niemców do idei litewskiej monarchii z księciem Urachem jako królem wpłynęły czynniki zewnętrzne. Widmo klęski Niemiec stawało się coraz bardziej realne, powodując zmiany personalne na szczytach władzy. Dnia 3 X nowym Kanclerzem Rzeszy został książę Max von Baden. Sekretarzem Stanu został M. Erzberger. Los uśmiechnął się do Litwinów. Już 5 X w Reichstagu kanclerz stwierdził, że mieszkańcy prowincji bałtyckich (w tym Litwy) mają pełne, suwerenne prawo do wyboru i ustalenia swoich konstytucji, a także relacji z sąsiadami oraz zapowiedział niezwłoczne ustanowienie rządów cywilnych. Swoje stanowisko potwierdził i przekazał, w szczegółowej wersji, delegacji litewskiej, którą przyjął $20 \mathrm{X}$. Cywilne władze prowincji miały sprawować swój mandat wyłącznie do czasu sformowania rządu przez Litwinów. Niemieckie wojska miały pozostać na terytorium Litwy dla zapewnienia bezpieczeństwa w okresie tymczasowym, po czym niezwłocznie powrócić do Rzeszy ${ }^{117}$. Wyrażono zgodę na sformowanie własnych sił zbrojnych $\mathrm{w}$ formie milicji, a także przyznano Litwie 10 mln marek pożyczki na tworzenie struktur władzy państwowej ${ }^{118}$.

Niepodległość Litwy została tym samym potwierdzona przez Niemcy. W ten sposób obawy przed aneksją do Rzeszy lub unią personalną $z$ Saksonią stały się nieaktualne. Nie było już powodu szybkiego osadzenia na tronie Wilhelma von Urach. Wobec deklaracji z $21 \mathrm{X}$ i dania Litwinom zarówno czasu na budowę struktur ustrojowych niepodległego państwa, jak i wolnej ręki w kwestii wyboru formy państwa idea monarchii znacznie straciła na atrakcyjności.

W dniu 2 XI 1918 r. Taryba jako najwyższa władza ustrojodawcza uchwaliła pierwszą litewską konstytucję tymczasową. Podstawą systemu władz była Taryba, określona jako władza najwyższa (suprema potestas). W jej składzie wyłoniono 3-osobowe prezydium pełniące funkcję kolegialnej głowy państwa. Prezydium wraz $\mathrm{z}$ powołanym przez nie rządem, złożonym $\mathrm{z}$ przewodniczącego i ministrów, było odpowiedzialne przed Tarybą. System ten miał

117 S.W. Page, op.cit., s. 95.

118 J. Ochmański, op.cit., s. 287. 
obowiązywać do czasu wyboru w sposób demokratyczny parlamentu, który miał określić przyszłą formę rządów ${ }^{119}$. Taryba wypowiedziała się tego dnia również wobec projektu osadzenia na tronie Wilhelma von Urach. Stwierdzono, że w obecnej sytuacji nie jest to możliwe, a ostateczną decyzję podejmie wybrana demokratycznie konstytuanta $^{120}$. Oznaczało to praktycznie koniec idei monarchicznej na Litwie ${ }^{121}$.

IV. Historia efemerycznych królestw Finlandii i Litwy jest pod wieloma względami wyjątkowa.

Przede wszystkim w obu przypadkach podwaliny niepodległego bytu państwowego zdecydowano się budować w oparciu o ideę monarchii konstytucyjnej, a nie republikę demokratyczną. Dla Finów wybór monarchii stanowił kontynuację procesu budowy podmiotowości politycznej narodu zapoczątkowanego utworzeniem Wielkiego Księstwa Finlandii w unii personalnej z Rosją, ale niezależnego od Szwecji. Dla Litwinów wybór ten był wynikiem pragmatycznej kalkulacji politycznej, ale również nawiązaniem do historycznej tradycji Królestwa Litwy.

Działacze niepodległościowi zarówno w Finlandii, jak i na Litwie wykazywali daleko posunięty sceptycyzm w kwestii dojrzałości własnych, młodych narodów do demokracji. Szansę na budowę, wzmocnienie i przetrwanie państwa wiązano raczej z osobą monarchy niż parlamentem czy prezydentem - podlegających politycznym naciskom oraz narażonych na typową zmienność i cykliczność demokratycznej władzy. Litwini obawiali się ponadto, czy uda się znaleźć wystarczającą liczbę osób mających odpowiednie wykształcenie, umiejętności i cechy charakteru, aby skompletować z nich

119 P. Kierończyk, op.cit., s. 32-33.

120 M. Maksimaitis, Lietuvos, s. 46. Z listu, który Wilhelm von Urach wysłał do M. Erzbergera (datowany na $30 \mathrm{X}$ ), wiemy, że A. Voldemaras, który kilka dni później został zaprzysiężony jako pierwszy premier rządu litewskiego, uprzedził księcia, że jego intronizacja nie dojdzie do skutku (S. von Cube, op.cit., s. 120-121). J. Wisner stwierdza wprost, że decyzja Taryby oznaczała anulowanie wyboru Wilhelma na króla Litwy (op.cit., s. 165).

121 J. Ochmański, op.cit., 2. 287. 
skład parlamentu. Przebudzenie narodowe Litwinów jeszcze trwało. Dynamika wydarzeń, jakie stały się udziałem Europy w okresie kończącej się wojny światowej, wymagało od nowo tworzących się państw powołania silnego ośrodka władzy zdolnego do szybkiego reagowania. Monarcha wydawał się odpowiedniejszy od uwikłanego w polityczne zależności prezydenta, kolegialnej głowy państwa czy parlamentu.

Uniezależnienie się od Rosji stanowiło ważny, ale tylko pierwszy etap budowy samodzielnego bytu państwowego. Dążenia niepodległościowe wymagały wsparcia politycznego, ekonomicznego i wojskowego ze strony wpływowego protektora. Wybór Niemiec wydawał się w ówczesnej sytuacji, wobec aktywności na tym polu dyplomacji i polityków niemieckich, sukcesów militarnych Niemiec odniesionych nad Rosją oraz wobec rezerwy ze strony państw ententy bezalternatywny. Oczywiście poparcie dla dążeń niepodległościowych narodów wchodzących w skład Cesarstwa Rosyjskiego stanowiło dla Niemiec przede wszystkim sposób osłabienia wroga (Rosji) oraz poszerzenia własnej strefy wpływów. Trudno doszukiwać się w nim poparcia dla samej idei irredentyzmu, która również dla Niemiec stanowiła zjawisko potencjalnie niebezpieczne.

Wśród czynników zewnętrznych, które wpłynęły zarówno na wybór sojusznika, jak i formę państwa wspomnieć należy o inspiracji, jaką oba państwa były dla siebie ${ }^{122}$, ale także jakim był dla Finów i Litwinów casus Polski (która również budowała swój niepodległy byt w oparciu o ideę monarchiczną, wspierana w tym przez Niemców). Kwestia polska miała szczególny wydźwięk w wypadku Litwy, której celem nie było wyłącznie uniezależnienie się od Rosji lub niepopadnięcie w nową zależność od Niemiec, ale także budowa suwerennych relacji z przyszłym państwem polskim i ewentualnie białoruskim, co na tle licznych pretensji terytorialnych i historycznych było sporym wyzwaniem ${ }^{123}$.

122 A. Janužytè, op.cit., s. 20.

123 Warto w tym miejscu wspomnieć projekt wspólnej, opartej na rządach monarchicznych federacji litewsko-łotewsko-białoruskiej projektowanej przez litewskich działaczy niepodległościowych jako wskrzeszenie Wielkiego Księstwa Litewskiego. Projekt konstytucji tego ciekawego tworu i kulisy jego powstania przybliża A. Grigaravičius (Lietuvos konstituciju 
Warto zaznaczyć, że w odróżnieniu od Polski, gdzie sięgnięcie po ideę monarchiczną w procesie uzyskiwania niepodległości miało raczej charakter wtórny i zewnętrzny, narzucony przez zaborców, Finowie i Litwini sami dokonali wyboru monarchicznej formy państwa jako optymalnego na wstępnym etapie budowania niepodległości. Jednocześnie, o ile polska Rada Regencyjna była organem fasadowym, pozbawionym istotnych kompetencji, a nawet politycznego znaczenia, o tyle w Finlandii i na Litwie kluczowym organem reprezentującym narodowe interesy i dążenia niepodległościowe pozostało ciało przedstawicielskie (Taryba, Eduskunta) stworzone oddolnie, a nie narzucone $z$ zewnątrz. Projekty ustroju monarchicznego w obu państwach zakładały utrzymanie tych ciał i ich istotny udział w sprawowaniu władzy, obok monarchy. Można więc uznać, że był to zabieg świadomy, pozwalający w warunkach dynamicznie zmieniającej się sytuacji politycznej zachować organ przedstawicielski symbolizujący narodowe aspiracje i poparcie dla idei niepodległości ${ }^{124}$.

Oprócz czynników zewnętrznych, które wpłynęły na wybór przez Finów i Litwinów monarchii, należy wspomnieć również czynniki o charakterze wewnętrznym - przede wszystkim tradycję i ciągłość historyczną państwa. Oba narody występowały pod hasłami odzyskania czy odbudowy niepodległości, a nie jej uzyskania ${ }^{125}$. Przykładowo - powołując niepodległą monarchię, Finowie sięgnęli po akt ustrojowy pochodzący z czasów sprzed nastania rosyjskiego panowania (1772 r.), a Litwini postanowili, że ich monarcha będzie nosił imię Mendoga II, a więc symbolicznego kontynuatora pierwszego i jedynego historycznego króla Litwy z XIII w. Element tożsa-

projektai, s. 352-357). O litewskich, białoruskich i polskich aspiracjach do kontynuacji idei Wielkiego Księstwa zob. T. Snyder, Rekonstrukcja narodów.Polska, Ukraina, Litwa, Białoruś 1569-1999, Sejny 2006.

124 Zob. M. Maksimaitis, Apie dvilypę, s. 10-13. Monarchia nie była jedynym pomysłem litewskich działaczy niepodległościowych (zob. A. Janužytė, op.cit., s. 22).

125 Nawiązywanie do tradycji i historii było popularne dla ówczesnych ruchów irredenty, również np. w Szkocji, Irlandii, Katalonii czy Norwegii. Litwini podkreślali, że źródłem ich dążeń niepodległościowych jest historyczna i etniczna „samoświadoość narodu” (zob. A. Janužytė, op.cit., s. 20). 
mości i historycznej ciągłości narodowej, bardzo ważny dla idei irredentyzmu, jako jej główne uzasadnienie, potrzebował wzmocnienia i ochrony. Monarcha doskonale się do tego celu nadawał, stanowiąc uosobienie historii, tradycji i kultury, wokół którego mógł jednoczyć się cały naród, bez względu na występujące w jego łonie różnice polityczne czy światopoglądowe. Tym zapewne należy tłumaczyć m.in. litewskie poparcie dla króla silnie przywiązanego do religii katolickiej czy nałożenie obowiązku nauki języka litewskiego na całą rodzinę panującą i jej otoczenie.

Wybór monarchii w przypadku państw w istocie budujących od nowa swoją państwowość, a więc niemogących odwołać się do historycznej dynastii - wiązał się z kolejną strategiczną decyzją dotyczącą znalezienia optymalnego kandydata do objęcia tronu i zapoczątkowania dynastii. W obu przypadkach wybór padł na książąt niemieckich $^{126}$. Skoro protektorem idei samostanowienia narodów fińskiego i litewskiego było państwo monarchiczne - Cesarstwo Niemiec, naturalnym polem poszukiwań kandydata na monarchę były Niemcy. Na tym tle uznaje się wybór przez Litwinów księcia Uracha jako właściwy zarówno ze względu na brak zainteresowania księcia współpracą z Polakami, odsunięcie Wettynów, którzy mogliby dążyć do reaktywacji unii personalnej saksońsko-litewsko-polskiej, jak również na chłodne relacje $z$ Hohenzollernami. Literatura przynosi dwie ciekawe informacje, które pozwalają nieco osłabić jednoznaczność tej oceny. Jednym $z$ kandydatów do tronu polskiego, którego nazwisko pojawia się $\mathrm{w}$ rozmowach prowadzonych pod koniec I wojny światowej, był syn Wilhelma, Karol Stefan von Urach. Jego kandydaturę do tronu polskiego aktywnie popierał m.in. Ruppert

126 Trafną, choć niepozbawioną nuty uszczypliwości charakterystykę środowiska książąt niemieckich nieposiadających praw do tronu, daje S. von Cube (op.cit., s. 115), pisząc, że ich przeznaczeniem była służba wojskowa w armiach innych królestw (jak diuk Aleksander Wirtemberski w armii Carycy Katarzyny II), rola pozbawionych uprawnień monarszych małżonków królowych (np. książę Albert von Sachsen-Coburg mąż królowej Wiktorii), próba objęcia obcego tronu (np. arcyksiążę Maksymilian von Habsburg - Cesarz Brazylii) lub detronizacja przez wydarzenia rewolucyjne z lat 1917-1918 (np. król Rumunii Michał von Hohenzollern). 
Wittelsbach, następca tronu Bawarii ${ }^{127}$. Personalna unia polsko-litewska nie była więc wykluczona również pod rządami książąt von Urach. Sam Wilhelm wkrótce po wyrażeniu zgody na swój wybór skierował do cesarza hołdowniczy list, w którym jednoznacznie deklarował swoją lojalność wobec Rzeszy jako przyszły król Litwy. Fakt ten można różnie interpretować - jako wybieg taktyczny lub dowód realizmu politycznego, a więc potwierdzenie słuszności wyboru osoby króla, ale także jako zapowiedź przyszłej uległości monarchy litewskiego wobec Cesarza Niemiec.

Klęska Niemiec w przypadku Finlandii i Litwy oznaczała zerwanie $z$ ideą monarchiczną i obranie kursu republikańskiego. Władca Niemiec stawał się w nowych okolicznościach kłopotliwym balastem. Nie oznacza to, że wcześniejszy wybór monarchii był błędem. Pozwolił na uzyskanie przez oba narody upragnionego potwierdzenia prawa do samostanowienia, a także na wejście na drogę konstytucjonalizmu. Późniejsze proklamowanie republik w Finlandii i na Litwie było więc już kolejnym etapem ich niepodległej historii, zapoczątkowanej przez monarchiczny prolog.

\section{SUMMARY}

\section{In search of the optimal form of the state at the threshold of independence. Kingdom of Finland and the Kingdom of Lithuania of 1918}

First World War is defined as the clash of two ideologies - monarchical, which embodiment was the Austro-Hungarian Empire and republican symbolized by the United States of America. Austria emerged from World War as a small country, barely shadow of its former power, also - a republic. United States advanced to the rank of a world power, and maintained this position throughout the twentieth century. The consequence of the

127 D. Szymczak, Między Habsburgami a Hohenzollernami. Rywalizacja niemiecko-austro-węgierska w okresie I wojny światowej, a odbudowa państwa polskiego, Kraków 2009, s. 289. 
war was to be the end of "ancieme regime" based on monarchies and the advent of the democratic republic and universal suffrage known as „Pax Americana". The main challenge that faced the builders of the postwar order was not royalism, but irredentism, as an aftermath of the disintegration of the great monarchies, which in Central Europe were the only factors of multi-national cohesion. A natural consequence of their fall was intensified development of nationalist ideas of strengthened by self-determination of peoples. For nations which did not have their own state, the primary issue was the decision about the form of a future political system. The choice of the Republican form of government perfectly fit in the idea for the new order based on democratic ideals. It turned out that this choice was not the only one possible. The idea of monarchy proved so attractive, that young nation-states appealed to that. This paper aims to present two examples of constitutional experiments, which used the idea of monarchy to implement the postulate of self-determination of nations - Finland (Kingdom of Finland) and Lithuania (Kingdom of Lithuania). Both proved to be ephemeral, which are in the literature generally ignored or treated as marginal. The task which the author has set himself is to attempt to answer the question about the reasons for choosing the monarchical form of the emerging political systems, and evaluate this choice.

Key-words: constitutional monarchy, Kingdom of Finland, Kingdom of Lithuania, irredentism, Mindaugas II, Taryba, Wilhelm von Urach, Eduskunta 